\title{
Mini-Hydrocyclone Separation of Cyanobacterial and Green Algae: Impact on Cell Viability and Chlorine Consumption
}

\author{
Saber Moradinejad ${ }^{1}$, Dries Vandamme ${ }^{2}{ }^{\mathbb{D}}$, Caitlin M. Glover ${ }^{1}$, Tahere Zadfathollah Seighalani ${ }^{1}$ \\ and Arash Zamyadi 1,3,* \\ 1 BGA Innovation Hub and Civil, Mineral, and Mining Engineering Department, 2900 Edouard Montpetit \\ Blvd, Montreal, QC H3T 1J4, Canada \\ 2 Applied and Analytical Chemistry (TANC), Institute for Materials Research (IMO), Hasselt University, \\ Martelarenlaan 42, 3500 Hasselt, Belgium \\ 3 Water Research Centre, School of Civil and Environmental Engineering, University of New South \\ Wales (UNSW), Sydney, NSW 2052, Australia \\ * Correspondence: arash.zamaydi@polymtl.ca or a.zamyadi@unsw.edu.au
}

Received: 28 May 2019; Accepted: 12 July 2019; Published: 16 July 2019

\begin{abstract}
The co-occurrence of non-toxic phytoplankton alongside cyanobacteria adds to the challenge of treating source waters with harmful algal blooms. The non-toxic species consume the oxidant and, thereby, reduce the efficacy of oxidation of both the extracellular and intracellular cyanotoxins. In this work, a 3D printed mini-hydrocyclone was used to separate a mixture of non-toxic green algae, Scenedesmus obliquus, from a toxic species of cyanobacteria, Microcystis aeruginosa. When water is pumped through the mini-hydrocyclone, cells exit through an overflow or underflow port depending on their size, shape, and density relative to the other cells and particles in the water matrix. The overflow port contains the cells that are smaller and less dense since these particles move toward the center of the hydrocyclone. In this work, the majority ( $>93 \%$ ) of Microcystis cells were found in the overflow while the underflow contained primarily the Scenedesmus ( $>80 \%$ ). This level of separation efficiency was maintained over the 30-min experiment and the majority of both cells (>86\%) remained viable following the separation, which indicates that the pumping combined with forces exerted within the mini-hydrocyclone were not sufficient to cause cell death. The impact of free chlorine on the cells both pre-separation and post-separation was evaluated at two doses ( 1 and $2 \mathrm{mg} / \mathrm{L})$. After separation, the overflow, which contained primarily Microcystis, had at least a $24 \%$ reduction in the free chlorine decay rate as compared to the feed water, which contained both species. This reduction in chlorine consumption shows that the cells separated via mini-hydrocyclone would likely require lower doses of oxidant to produce a similar level of degradation of the cyanotoxins present in either the extracellular or intracellular form. However, future work should be undertaken to evaluate this effect in natural bloom samples.
\end{abstract}

Keywords: 3D printing; hydrocyclone; separation; chlorination; cyanobacteria; green algae

\section{Introduction}

Phytoplankton, i.e., cyanobacteria, dinoflagellates, green algae, and diatoms, in surface waters are significant contributors to the total carbon biomass pool [1]. Current estimates for this fraction range from $10 \%$ for an average across the lakes of the United States (U.S.) up to $25 \%$ to $50 \%$ for a reservoir in southern Australia and 20\% to 40\% for two lakes in Michigan, U.S. [1-3]. As climate change and human activities lead to increases in the eutrophication of lakes and higher temperatures, this fraction 
is likely to increase. This is particularly true for cyanobacteria, which favor these conditions over other phytoplankton, e.g., diatoms and dinoflagellates [4].

Treating the biomass from phytoplankton in source waters is a challenge for drinking water treatment plants. It can result in treatment upsets due to filtration breakthrough [5-7] and increased formation of disinfection byproducts $[5,8]$. Cyanobacteria also have the potential to accumulate and/or grow within the treatment plant (e.g., clarifier sludge, surface of clarifiers, and gravity filters) or the water recycling system (e.g., sludge of gravity thickener for backwash water/dissolved air floatation filtration water) $[6,9]$. The accumulation and breakthrough of cells requires additional treatment due to the potential for cells to release secondary metabolites, e.g., taste and odor (T\&O) compounds and cyanotoxins. Cyanotoxins are of concern because they can cause gastrointestinal, skin, liver, and neurological effects and are linked to cancer, Alzheimer's disease, and motor neuron disease [10-13]. Although $\mathrm{T} \& \mathrm{O}$ compounds are not a risk to human health, they cause customer complaints and lower confidence in the water treatment process [14]. Both cyanobacteria and select species of dinoflagellates and green algae produce $\mathrm{T} \& \mathrm{O}$ compounds [15-17].

When harmful cyanobacteria enter the water treatment process, they will often co-occur with species that do not produce cyanotoxins or T\&O compounds. The presence of non-harmful species reduces the efficiency of all stages of treatment, including oxidation [6,8]. Previous work has shown that the presence of a mixed species bloom requires additional ozone, chlorine, and potassium permanganate to kill-off the cells and detracts from the efficient oxidation of cyanotoxins $[6,8,18]$. Separating the harmful and non-toxic species from one another would allow for more precise dosing and efficient oxidation. Although water treatment plants do not currently use any techniques for separating cells from one another, full-scale separation techniques have been applied in commercial applications, i.e., biofuels, cosmetics, medicinal products, bio-plastics, and supplements [19]. However, many of the current methods are limited by high energy and operating costs and long operation times.

Recently, a 3D-printed mini-hydrocyclone was optimized to separate phytoplankton [19]. The 3D-printed mini-hydrocyclone is passive, low cost, and generally low energy and the microfluidic technique takes advantage of differences in size, density, and morphology to separate cells. A pump is used to push water through the mini-hydrocyclone where two vortices form, which includes an overflow vortex and an underflow vortex (Figure 1). The underflow will contain the cells and particles that are larger, denser, and heavier whereas the overflow will contain smaller, less dense cells. Particles that are not well-settled may exit through both the under-flow and overflow ports. The mini-hydrocyclone can separate the particles in the size range of 5 to $20 \mu \mathrm{m}$ [19], which is well within the general size range for cyanobacterial $(0.5-40 \mu \mathrm{m})$ and green algae $(0.5-1000 \mu \mathrm{m})$ [20]. This novel technique has been evaluated under a limited set of conditions. Ref. [19] employed the mini-hydrocyclone to concentrate cells by removing water from a valuable commercial species of phytoplankton, Tetraselmis seucica. The efficient concentration produced a final cell count seven times greater than the original [19].

In this work, a 3D printed mini-hydrocyclone was employed to separate a toxic Microcystis aeruginosa (cyanobacteria) from a non-toxic Scenedesmus obliquus (green algae). These two species were selected since they reflect two of the dominant types of algae, cyanobacteria, and chlorophyceae, found in North America [21]. A prediction of which species would exit through the overflow vs. the underflow was calculated using knowledge of cell density, size, and shape. These predicted results were then compared against the operation of the mini-hydrocyclone and the separated species were examined to determine the efficiency of the technique, the viability of the cells, and the effect on the consumption of chlorine. 

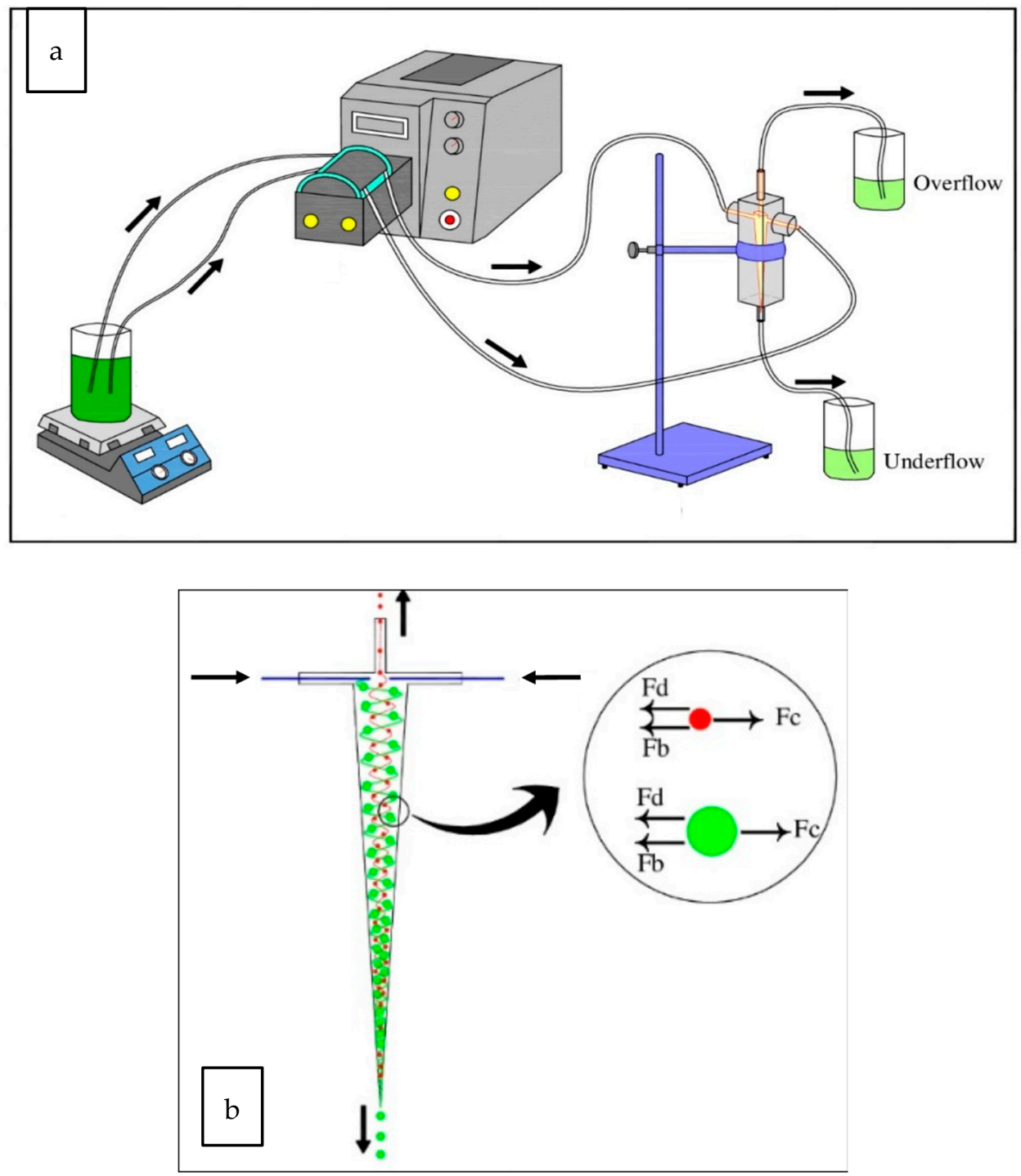

Figure 1. (a) Experimental set-up with the peristatic pump pushing a mixture of the two species, Microcystis and Scenedesmus, through the mini-hydrocyclone and into overflow and underflow beakers. (b) Hydrocyclone produced by pumping cells allows species to exit via the underflow and overflow ports. Pop-out shows the forces acting on cells within the hydrocyclone: the drag force $\left(\mathrm{F}_{\mathrm{d}}\right)$, the buoyance force $\left(\mathrm{F}_{\mathrm{b}}\right)$, and the centrifugal force $\left(\mathrm{F}_{\mathrm{c}}\right)$.

\section{Materials and Methods}

\subsection{Mini-Hydrocyclone Fabrication}

The AutoCAD design for the 3D model of an optimized version of the mini-hydrocyclone was generated in [19] and the design information is available in their Electronic Supporting Information. Printing was completed with an Ultimaker 3 (Utrecht, The Netherlands) and the polylactic acid (plastic) model was polished and strengthened with a vapor acetone chamber prior to use. The 3D mini-hydrocyclone was mounted via a ring-stand and connected to a peristaltic pump for experimentation (Figure 1). The peristaltic pump was run at a flow rate of $50 \mathrm{~mL} / \mathrm{min}$ for a total of $30 \mathrm{~min}$, which was the time required to process the sample volume of $1500 \mathrm{~mL}$. Overflow and underflow samples were collected after 5, 10, 20, and $30 \mathrm{~min}$ and analyzed to determine cell integrity and species analysis. Chlorination experiments were conducted on the mixed sample prior to separation as well as the overflow and underflow samples collected after a 30-min pumping time. The specifics of cell analysis and chlorination will be discussed in the next section. 


\subsection{Preparation of the Phytoplankton Mixture and Chlorination}

Two strains, Microcystis aeruginosa (hereafter referred to as Microcystis) and Scenedesmus obliquus (hereafter referred to as Scenedesmus), were cultured in Z8 sterilized artificial medium. The cells were purchased from the Canadian Phycological Culture Center (CPCC). The cultures were maintained at $21{ }^{\circ} \mathrm{C}$ with $12 \mathrm{~h}$ of florescent light exposure followed by $12 \mathrm{~h}$ of darkness. The mixture created for separation with the mini-hydrocyclone had a ratio of cyanobacteria:green algae of 60:40 (Microcystis:Scenedesmus) with the cell numbers of approximately 31,000 to 21,000 cells/mL. The cultured cells were transferred into either lab-grade deionized (DI) water or a natural water sample from Lake Champlain. The natural water sample was collected from the intake of the Bedford Water Treatment Plant in Southern Quebec, Canada and had $5 \mathrm{mg} / \mathrm{L}$ of DOC and a $\mathrm{pH}$ of 6.8.

Two chlorine doses ( 1 and $2 \mathrm{mg} / \mathrm{L}$ ) were applied to the mixture of phytoplankton in DI water and the separated overflow sample. The N,N-diethyl-p-phenylenediamine (DPD) colorimetric method was used to determine the chlorine stock and chlorine residual concentration according to Standard Methods 4500-Cl G [22]. Following the 15 min of contact time, samples were quenched with $3 \mathrm{~g} / \mathrm{L}$ of sodium thiosulfate. Experiments were conducted at room temperature or approximately $20{ }^{\circ} \mathrm{C}$. To compare the impact of chlorine on the different samples, chlorine decay rates were calculated using Equation (1).

$$
\mathrm{C}=\mathrm{C}_{0} \mathrm{e}^{-\mathrm{kt}}
$$

$\mathrm{C}$ was the chlorine concentration $(\mathrm{mg} / \mathrm{L})$ at a given time, $\mathrm{C}_{0}$ was the chlorine dose applied $(\mathrm{mg} / \mathrm{L})$, $\mathrm{k}$ was the rate $\left(\mathrm{s}^{-1}\right)$, and $\mathrm{t}$ was the time $(\mathrm{s})$.

\subsection{Cell Integrity and Counting Methods}

An inverted microscope was used to count cells in the feed water mixed species, overflow, and underflow samples after preservation with Lugol's iodine [23]. For cell integrity, simultaneous fluorescent cell-staining was applied and analyzed with a BD Accuri C6 Flow Cytometer (BD, Oxford, UK), as described in [6]. The two stains applied were fluorescein diacetate (FDA) and propidium iodide (PI). FDA passes through cell membranes and, if a cell is metabolically active, the FDA will be hydrolyzed by the cell-bound esterase and produce a yellow-green fluorescent product. While PI is itself a red fluorescent compound that penetrates damaged cells and binds with nucleic acids.

\subsection{Theoretical Separation Calculations}

The mini-hydrocyclone separates suspended cells by the rotational flow or vortices and three forces act on each cell including the centrifugal force $\left(\mathrm{F}_{\mathrm{c}}\right)$, the buoyant force $\left(\mathrm{F}_{\mathrm{b}}\right)$, and the drag force $\left(F_{d}\right)$ (Figure $1 b$ ). The $F_{c}$ moves cells outward as a result of the flow velocity. The $F_{b}$ moves cells toward the inner part of the hydrocyclone based on the difference between the density of the water (e.g., DI water or Lake Champlain water) and the cells. The $F_{d}$ pushes on cells in the opposite direction of the velocity of the cells, which are moving, and depends on the viscosity of the fluid.

To determine if the cells in this work could be easily separated using this technique, initial calculations were completed to validate the experiment. By summing the forces acting on these cells, a net total force can be calculated that will determine if the cells will be present in the underflow or the overflow (Equations (2)-(4)). These forces depend on the diameter of the cell $\left(D_{c}, m\right)$, the density of the cell $\left(\rho_{\mathrm{c}}, \mathrm{kgm}^{-3}\right)$ at a specific radial distance $(\mathrm{r}, \mathrm{m})$, density of the fluid $\left(\rho_{\mathrm{f}}, \mathrm{kgm}^{-3}\right)$, the tangential $\left(v_{\mathrm{t}}\right.$, $\mathrm{m} / \mathrm{s})$ and radical velocity $\left(v_{\mathrm{r}}, \mathrm{ms}^{-1}\right)$ of the cells, and the viscosity of the DI water or Lake Champlain sample $\left(\eta, \mathrm{kgm}^{-1} \mathrm{~s}^{-1}\right)$ [19].

$$
\begin{gathered}
\mathrm{F}_{\mathrm{b}}=-\frac{\pi \mathrm{D}_{\mathrm{c}}^{3}}{6} \frac{\mathrm{V}_{\mathrm{t}}^{2}}{\mathrm{r}} \rho_{\mathrm{c}} \\
\mathrm{F}_{\mathrm{c}}=\frac{\pi \mathrm{D}_{\mathrm{c}}^{3}}{6} \frac{\mathrm{V}_{\mathrm{t}}^{2}}{\mathrm{r}} \rho_{\mathrm{f}}
\end{gathered}
$$




$$
\mathrm{F}_{\mathrm{d}}=-3 \pi \mathrm{D}_{\mathrm{C}} \eta v_{\mathrm{r}}
$$

Relative to the other two forces, the drag force will not be a significant actor for phytoplankton cells [19]. Therefore, to determine the total forces, the centrifugal force was subtracted from the buoyance force to determine the net effect on these cyanobacterial cells as compared to green algae. With the constant parameters removed in Equation (5), the total estimated force depends on the diameter and density of cells as compared to the density of the fluid (in this case, water).

$$
\text { Estimated total force }=\mathrm{D}_{\mathrm{c}}^{3} \times\left(\rho_{\mathrm{c}}-\rho_{\mathrm{f}}\right)
$$

In the force equation, the diameter of cells is the most significant contributor to the overall value, but the sign of the force is determined by the density of cells relative to the density of water. Negative values for the estimated force would mean that the cells move toward the center of the hydrocyclone and wind up in the overflow. The positive sign means particles will move toward the edge of the hydrocyclone and exit via the underflow. The diameter of Microcystis aeruginosa $(5 \mu \mathrm{m})$ is slightly lower than that of the Scenedesmus obliquus $(10 \mu \mathrm{m})$, but, as mentioned above, the density of the cells will likely determine the overall sign of the total force [24]. The density of phytoplankton can vary between genera and species, the size of the colony, and the stage in the growth cycle $[25,26]$. Cyanobacteria specifically have evolved the ability to alter their density via gas vesicle volume, which allows them to respond to environmental variables, e.g., light levels and nutrient concentrations, and outcompete other phytoplankton that cannot move within the water column [4,26]. An analysis of Microcystis aeruginosa collected over several months in Lake Taihu, China showed densities of 990 to $995 \mathrm{~kg} \mathrm{~m}^{-3}$ [27] with similar values of 985 to $1005 \mathrm{~kg} \mathrm{~m}^{-3}$ generated in earlier work [28]. For the Scenedesmus obliquus, the literature density ranges were less constrained with a maximum value of $1310 \mathrm{~kg} \mathrm{~m}^{-3}$ [29] and a minimum of $1070 \mathrm{~kg} \mathrm{~m}^{-3}$ [30]. Based on estimation of total force as shown in Table 1, regardless of the specific densities used for these cell cultures, the Microcystis and Scenedesmus will be found in the overflow and the underflow, respectively. This demonstrates that the two species should be separated from one another, but efficacy of this separation will be examined further in the results section.

Table 1. Estimated total force calculations from cell densities and cell diameter for Microcystis and Scenedesmus and the resulting outlet for the cells after separation with the mini-hydrocyclone.

\begin{tabular}{ccccc}
\hline Cell Type & $\begin{array}{c}\text { Cell Diameter } \\
(\mu \mathbf{m})\end{array}$ & $\begin{array}{c}\text { Density } \\
\left(\mathbf{k g ~ m}^{-3}\right)\end{array}$ & $\begin{array}{c}\text { Estimated Total } \\
\text { Force }\end{array}$ & $\begin{array}{c}\text { Overflow or } \\
\text { Underflow }\end{array}$ \\
\cline { 1 - 4 } $\begin{array}{c}\text { Microcystis } \\
\text { aeruginosa }\end{array}$ & 5 & 985 & -1250 & Overflow \\
\cline { 2 - 4 } $\begin{array}{c}\text { Scenedesmus } \\
\text { obliquus }\end{array}$ & 5 & 1005 & 1250 & Underflow \\
\cline { 2 - 4 } & 10 & 1070 & 75,000 & \\
\hline
\end{tabular}

\section{Results and Discussion}

\subsection{Separation Efficiency of Mini-Hydrocyclone}

The mini-hydrocyclone was run for a total of $30 \mathrm{~min}$, with samples collected every $5 \mathrm{~min}$ for the duration of the experiment. The overflow, underflow, and initial mixture of cells in the Lake Champlain water were examined for the fraction of Microcystis and Scenedesmus present as well as the viability of these cells. As predicted in the methods section, the overflow primarily contained Microcystis and the underflow primarily contained Scenedesmus (Figure 2). The overflow contained a higher average concentration of Microcystis at $2.7 \times 10^{4} \pm 0.13$ cells $/ \mathrm{mL}$ whereas $1.5 \times 10^{4} \pm 0.08$ cells $/ \mathrm{mL}$ Scenedesmus cells were detected in the underflow due to the initial 60:40 ratio (Figure 2). The separation of cells was consistent over time in both the underflow and overflow samples with the number of cells present after $5 \mathrm{~min}$, which is similar to those at $30 \mathrm{~min}$. 


\section{a. Overflow (Lake Champlain)}

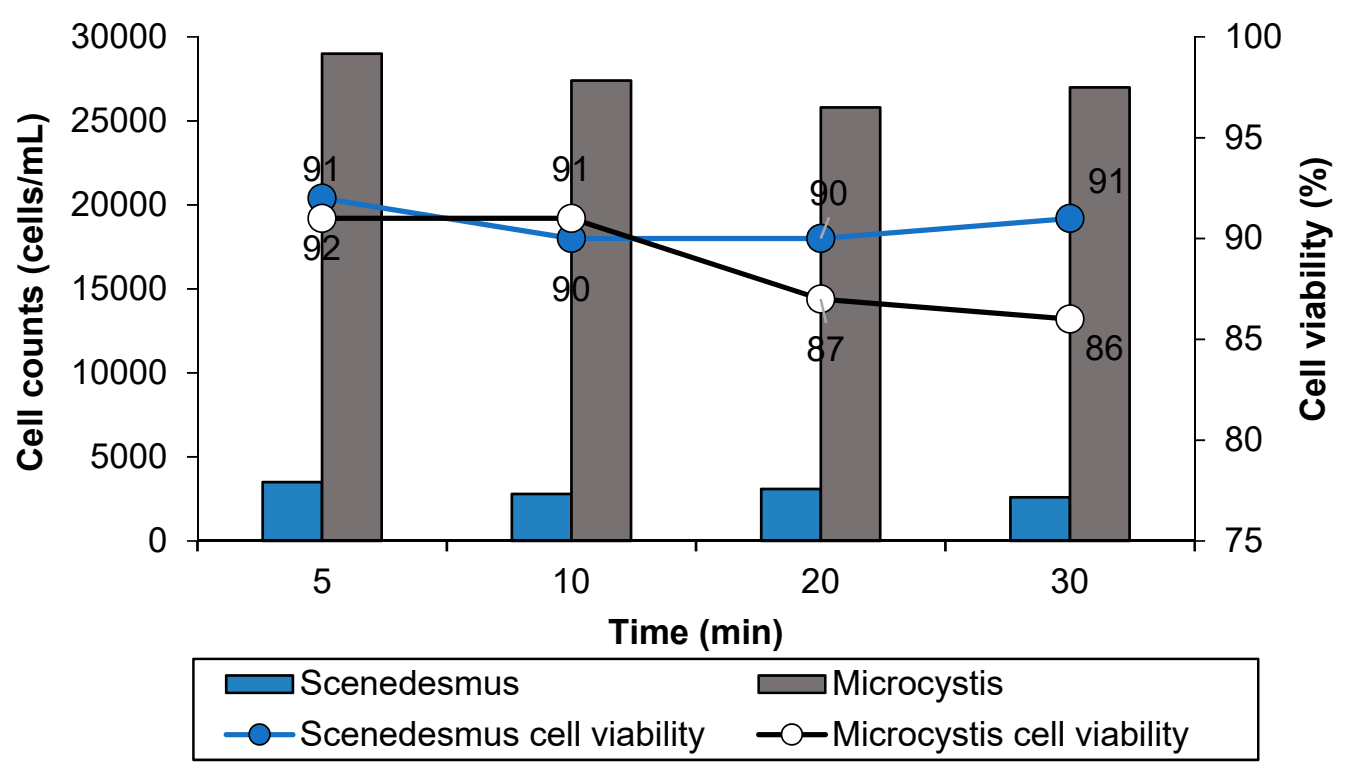

b. Underflow (Lake Champlain)

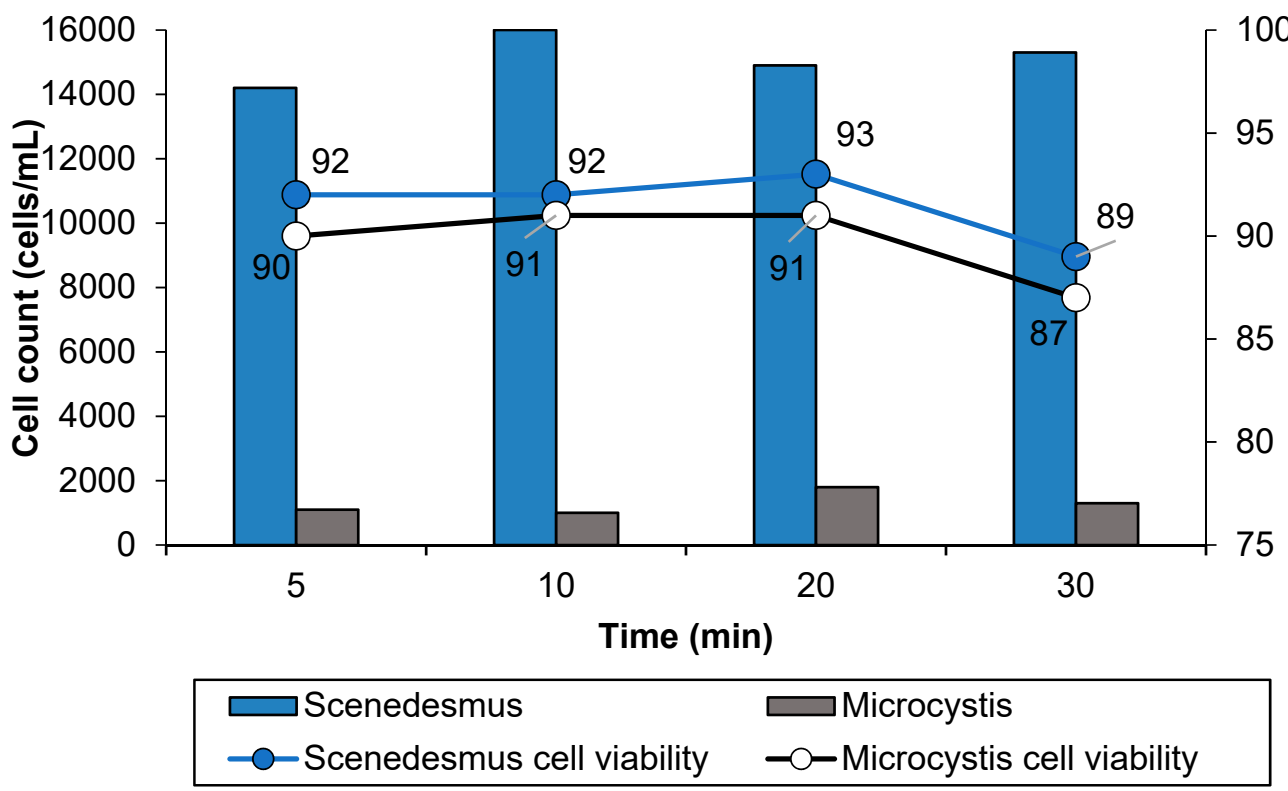

Figure 2. The concentration of Microcystis and Scenedesmus cells present (left axis) and the viability of those cells (right axis) over time when spiked into Lake Champlain water in the overflow (a) and underflow (b).

The majority $(>86 \%)$ of separated cells were viable, which indicates that the separation process did not result in the death of cells (Figure 2). However, for the Microcystis in the overflow sample, the percent viable ranged from $92 \%$ to $86 \%$ with an average of $89 \pm 2.6 \%$. The Scenedesmus cells found in the overflow remained at an average of $91 \pm 0.96 \%$, which is viable throughout the experiment. Cells have varying tolerance to shear stress with green algae generally found to be more resistant to cell lysis relative to other phytoplankton [31,32]. A similar trend has been observed with oxidation of cells where green algae have been shown to be more resistant to oxidation relative to cyanobacteria species like Microcystis via ozone, potassium permanganate, and hydrogen peroxide $[6,33,34]$.

Although Figure 2 shows the separation of cells in Lake Champlain water, cells were also spiked into the DI water and a comparison of the separation efficiency for these two background matrices 
can be found in Figure 3. The separation efficiency was calculated by determining the number of Microcystis cells in the overflow and dividing this number by the sum of the number of Microcystis cells found in the overflow and in the underflow [19]. Although the target species in this work is the cyanobacteria, the efficiency for the underflow cells can also be determined. This scenario would be useful if the targeted species is larger and/or more dense phytoplankton than the species it is being separated from.

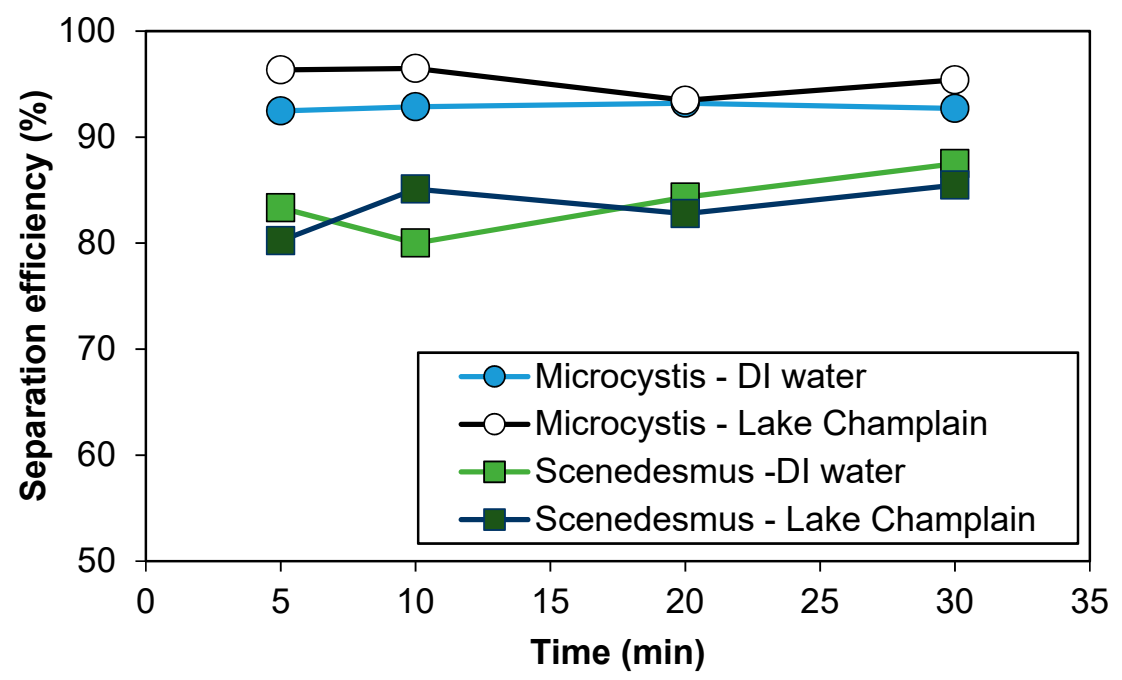

Figure 3. Separation efficiency of cells in the overflow and underflow of the mini-hydrocyclone over time.

The separation efficiency generated in Lake Champlain water was slightly higher than the DI water for the Microcystis cells, but no difference was observed for the Scenedesmus cells (Figure 3). For Microcystis, this efficiency was an average of $95 \pm 1.4 \%$ in the Lake Champlain water and $93 \pm 0.30 \%$ in DI water. In this case, the separation of Scenedesmus cells in the underflow was less efficient at $84 \pm 3.1 \%$ in the DI water and $83 \pm 2.4 \%$ in the Lake Champlain water. Over the experiment time period (up to $30 \mathrm{~min}$ ), no difference was observed with the separation efficiency between the two background matrices highlighting the suitability of the mini-hydrocyclone for potential use in natural waters.

Although Table 1 shows that the Microcystis and Scenedesmus will be effectively separated, cell density and size can change depending on the stage of the growth cycle. In this work, it is possible that Scenedesmus or Microcystis cells were found in the overflow or underflow because they did not match the average size or density measurements gathered from literature values. To fully understand the potential impact of various sizes and density cells that have on the separation efficiency, natural blooms should be tested. This would also provide information on how the presence of other species of phytoplankton impact the separation of toxic cyanobacteria. Another limitation of this analysis is that Microcystis cells are often found aggregated together in colonies protected by a slime or sheath layer. The diameter of these colonies can range from $<100 \mu \mathrm{m}$ up to $>1000 \mu \mathrm{m}$ [35]. The efficacy of separation would be impacted by the size of the colonies and their ability to retain a cohesive structure. If the colonies were on the smaller side and able to stay together, they could be effectively separated from the smaller Scenedesmus cells. However, if the select cells were to break off from a colony, they would likely be poorly separated since the individual Microcystis cells would be smaller than the Scenedesmus cells, but those in colonies would be larger.

\subsection{Impact of Separation of Chlorine Consumption}

After the mini-hydrocyclone was used to separate cells, the chlorine decay was determined. Two doses ( 1 and $2 \mathrm{mg} / \mathrm{L}$ ) were applied to the mixed cells prior to separation and the cells in the overflow (>90\% Microcystis) (Figure 4). To achieve first-order reaction kinetics, oxidant decay rates were broken 
into two phases, $\mathrm{k}_{\text {fast }}$ and $\mathrm{k}_{\text {slow }}[8,18,36]$. The first rate includes the rapid reactions occurring within 1 min of oxidant dose application and the second, comparatively slow, rate was calculated after $>1$-min through 15 -min or until there was no residual detected. The $\mathrm{R}^{2}$ values associated with the $\mathrm{k}_{\text {slow }}$ reaction rates were $>0.90$ for all samples.

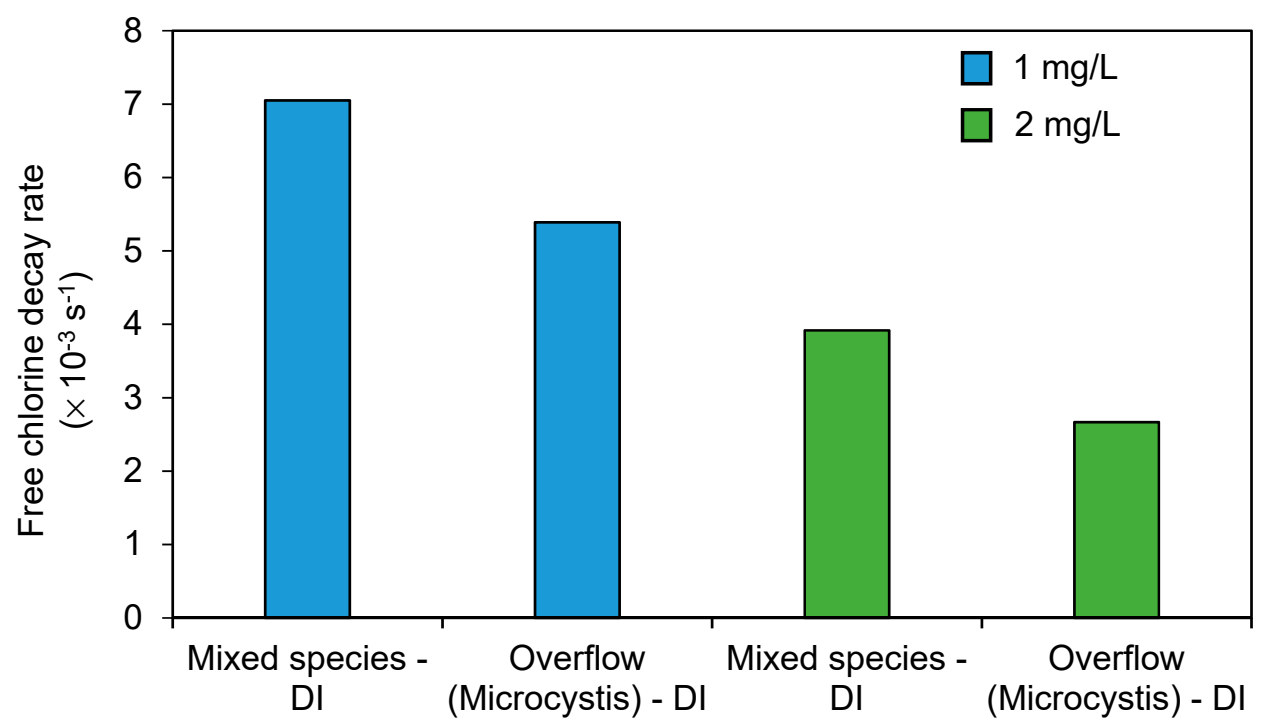

Figure 4. Impact of separation on the chlorine decay rate for the mixed species (feed water with Microcystis and Scenedesmus) and the overflow (>93\% Microcystis) in DI water. Samples were collected from the mini-hydrocyclone after $30 \mathrm{~min}$.

The decay rates determined for the mixed species in DI water were $7.05 \times 10^{-3} \mathrm{~s}^{-1}(1 \mathrm{mg} / \mathrm{L})$ and $3.92 \times 10^{-3} \mathrm{~s}^{-1}(2 \mathrm{mg} / \mathrm{L})$ (Figure 4). These decay rates are similar to the one observed in a full-scale cyanobacteria bloom $\left(1.0 \times 10^{-3} \mathrm{~s}^{-1}, 2 \mathrm{mg} / \mathrm{L}\right.$ free chlorine and $5.7 \times 10^{5}$ cells $\left./ \mathrm{mL}\right)$ containing primarily Microcystis (82\%) [37]. The minor differences are likely due to the background organic matter. The separation of cells effectively reduced the rate of decay by $24 \%(1 \mathrm{mg} / \mathrm{L})$ and $30 \%(2 \mathrm{mg} / \mathrm{L})$ to $5.38 \times 10^{-3} \mathrm{~s}^{-1}$ and $2.67 \times 10^{-3} \mathrm{~s}^{-1}$, respectively (Figure 4). This effect is likely due to a combination of the overflow containing a lower number of cells and the presence of a monoculture instead of mixed species. Although this result is promising for its potential optimization of chlorine treatment and the removal of cyanotoxins, additional work must be conducted to better understand the impact of chlorinating natural bloom samples after separation via mini-hydrocyclone.

The decay rates generated for Microcystis after separation were significantly higher than those observed for other monocultures. For example, a monoculture of Microcystis aeruginosa cells both in DI water and in a natural water sample ranged from 6.4 to $8.2 \times 10^{-5} \mathrm{~s}^{-1}\left(10^{4}\right.$ cells $/ \mathrm{mL}$ and $2 \mathrm{mg} / \mathrm{L}$ of free chlorine) [18]. Similarly, Anabaena circinalis ( $2 \mathrm{mg} / \mathrm{L}$ free chlorine and $4.6 \times 10^{4} \mathrm{cells} / \mathrm{mL}$ ) had a lower rate of $4.6 \times 10^{-4} \mathrm{~s}^{-1}$ [38]. The rapid decay rate observed in this work was attributed to potential differences in the $\mathrm{pH}$ as well as cell-specific reactivity, e.g., growth phase and membrane thickness $[8,18]$, but this result could also be an indicator that the Scenedesmus cells are the driver for chlorine consumption. Their presence in the overflow altered the consumption of chlorine.

\section{Conclusions}

In this work, the 3D printed mini-hydrocyclone was able to efficiently and quickly separate cells without losing consistency over a 30-min experiment period. Specifically, the technique allowed for the Microcystis and Scenedesmus to be separated from one another with $>93 \%$ and $>80 \%$ efficiency, respectively. 
The forces exerted on cells via the hydrocyclone did not result in significant cell death with $>86 \%$ of all cells remaining viable after separation. This is a positive outcome for treatment because the cells did not release their cyanotoxins or T\&O compounds during the separation process.

The chlorination of cells post-separation reduced the consumption of chlorine and resulted in decay rates that were at least $24 \%$ lower. However, additional research with other commonly used water treatment oxidants and a broader range of doses needs to be completed.

Overall, the mini-hydrocyclone is a promising new technique for the separation of cyanobacteria, but it requires significant additional vetting of its efficacy over longer experimental periods and with more complex natural bloom waters.

Author Contributions: S.M., D.V., and A.Z. conceived and designed the experiments. S.M. and T.Z.S. performed the experiments and analyzed the samples. S.M., D.V., C.M.G., T.Z.S., and A.Z. analyzed the data. S.M., D.V., C.M.G., T.Z.S., and A.Z. wrote and edited the paper.

Funding: This research was funded by Natural Sciences and Engineering Research Council of Canada (NSERC) Discovery Grants Program, and The Fonds de recherche du Québec-Nature et technologies (FRQNT) "Établissement de nouveaux chercheurs universitaires" grant program.

Conflicts of Interest: The authors declare no conflict of interest.

\section{References}

1. Tomlinson, A.; Drikas, M.; Brookes, J.D. The role of phytoplankton as pre-cursors for disinfection by-product formation upon chlorination. Water Res. 2016, 102, 229-240. [CrossRef] [PubMed]

2. Linden, L.G.; Lewis, D.M.; Burch, M.D.; Brookes, J.D. Interannual variability in rainfall and its impact on nutrient load and phytoplankton in Myponga Reservoir, South Australia. Int. J. River Basin Manag. 2004, 2, 169-179. [CrossRef]

3. Bade, D.L.; Carpenter, S.R.; Cole,J.J.; Pace, M.L.; Kritzberg, E.; Van de Bogert, M.C.; Cory, R.M.; McKnight, D.M. Sources and fates of dissolved organic carbon in lakes as determined by whole-lake carbon isotope additions. Biogeochemistry 2007, 84, 115-129. [CrossRef]

4. Paerl, H.W. Mitigating Toxic Planktonic Cyanobacterial Blooms in Aquatic Ecosystems Facing Increasing Anthropogenic and Climatic Pressures. Toxins 2018, 10, 76. [CrossRef] [PubMed]

5. Zamyadi, A.; Dorner, S.; Sauvé, S.; Ellis, D.; Bolduc, A.; Bastien, C.; Prévost, M. Species-dependence of cyanobacteria removal efficiency by different drinking water treatment processes. Water Res. 2013, 47, 1080-1090. [CrossRef] [PubMed]

6. Zamyadi, A.; Romanis, C.; Mills, T.; Neilan, B.; Choo, F.; Coral, L.A.; Gale, D.; Newcombe, G.; Crosbie, N.; Stuetz, R.; et al. Diagnosing water treatment critical control points for cyanobacterial removal: Exploring benefits of combined microscopy, next-generation sequencing, and cell integrity methods. Water Res. 2019, 152, 96-105. [CrossRef] [PubMed]

7. Pazouki, P.; Prevost, M.; McQuiad, N.; Barbeau, B.; de Boutray, M.-L.; Zamyadi, A.; Dorner, S. Breakthrough of cyanobacteria in bank filtration. Water Res. 2016, 102, 170-179. [CrossRef]

8. Zamyadi, A.; Coral, L.A.; Barbeau, B.; Dorner, S.; Lapolli, F.R.; Prévost, M. Fate of toxic cyanobacterial genera from natural bloom events during ozonation. Water Res. 2015, 73, 204-215. [CrossRef]

9. Zamyadi, A.; Henderson, R.K.; Stuetz, R.; Newcombe, G.; Newton, K.; Gladman, B. Cyanobacterial management in full-scale water treatment and recycling processes: Reactive dosing following intensive monitoring. Environ. Sci. Water Res. Technol. 2016, 2, 362-375. [CrossRef]

10. Chorus, I.; Bartram, J. Toxic Cyanobacteria in Water: A Guide to Their Public Health Consequences, Monitoring and Management; World Health Organization (WHO): London, UK, 1999.

11. Holtcamp, W. The emerging science of BMAA: Do cyanobacteria contribute to neurodegenerative disease? Environ. Health Perspect. 2012, 120, a110-a116. [CrossRef]

12. Bradley, W.G.; Borenstein, A.R.; Nelson, M.; Codd, G.A.; Rosen, B.H.; Stommel, E.W.; Cox, P.A. Is exposure to cyanobacteria an environmental risk factor for amyotrophic lateral sclerosis and other neurodegenerative disease? Amyotroph. Lateral Scler. Frontotemporal Degener. 2013, 14, 325-333. [CrossRef] [PubMed] 
13. Chernoff, N.; Hill, D.J.; Diggs, D.L.; Faison, B.D.; Francis, B.M.; Lang, J.R.; Larue, M.M.; Le, T.-T.; Loftin, K.A.; Lugo, J.N.; et al. A critical review of the postulated role of the nonessential amino acid, b-N-methylamino-L-alanine, in neurodegenerative disease in humans. J. Toxicol. Environ. Health 2017, 20, 183-229. [CrossRef] [PubMed]

14. Suffet, I.H.; Corado, A.; Chou, D.; McGuire, M.J.; Butterworth, S. AWWA taste and odor survey. JAWWA 1996, 88, 168-180. [CrossRef]

15. Watson, S.B.; Ridal, J.; Boyer, G.L. Taste and odour and cyanobacterial toxins: Impairment, prediction, and management in the Great Lakes. Can. J. Fish. Aquat. Sci. 2008, 65, 1779-1796. [CrossRef]

16. Satchwill, T.; Watson, S.B.; Dixon, E. Odourous algal-derived alkenes: Differences in stability and treatment responses in drinking water. Water Sci. Technol. 2007, 55, 95-102. [CrossRef] [PubMed]

17. Jüttner, F.; Watson, S.B. Biochemical and ecological control of geosmin and 2-methylisoborneol in source waters. Appl. Environ. Microbiol. 2007, 73, 4395-4406. [CrossRef] [PubMed]

18. Zamyadi, A.; Fan, Y.; Daly, R.I.; Prevost, M. Chlorination of microcystis aeruginosa: Toxin release and oxidation, cellular chlorine demand and disinfection by-products formation. Water Res. 2013, 47, 1080-1090. [CrossRef]

19. Syed, M.S.; Rafeie, M.; Henderson, R.; Vandamme, D.; Asadnia, M.; Ebrahimi Warkiani, M. A 3D-printed mini-hydrocyclone for high throughput particle separation: Application to primary harvesting of microalgae. Lab Chip 2017, 17, 2459-2469. [CrossRef]

20. Maier, R.; Pepper, I.L.; Gerba, C.P. Environmental Microbiology, 2nd ed.; Academic Press, Elsevier: Cambridge, MA, USA, 2009.

21. Kommineni, S.; Amante, K.; Karnik, B.; Sommerfeld, M.; Dempster, T. Strategies for Controlling and Mitigating Algal Growth within Water Treatment Plants; Water Research Foundation: Denver, CO, USA, 2009.

22. American Public Health Association (APHA). Standard Methods for the Examination of Water and Wastewater; American Water Works Association, Water Environment Federation: Washington, DC, USA, 2012.

23. Lund, J.W.G.; Kipling, C.; Le Cren, E.D. The inverted microscope method of estimating algal number and the statistical basis of estimations by counting. Hydrobiologia 1958, 11, 143-170. [CrossRef]

24. Henderson, R.; Parson, S.A.; Jefferson, B. The impact of algal properties and pre-oxidation on solid-liquid separation of algae. Water Res. 2008, 42, 1827-1845. [CrossRef]

25. Walsby, A.E. Gas vesicles. Microbiol. Rev. 1994, 58, 94-144. [CrossRef] [PubMed]

26. Oliver, R. Floating and sinking in gas-vacuolate cyanobacteria. J. Phycol. 1994, 30, 161-173. [CrossRef]

27. Li, M.; Zhu, W.; Guo, L.; Hu, J.; Chen, H.; Xiao, M. To increase size or decrease density? Different Microcystis species has different choice to form blooms. Sci. Rep. 2016, 6, 37056. [CrossRef] [PubMed]

28. Reynolds, C.S.; Oliver, R.L.; Walsby, A.E. Cyanobacterial dominance: The role of buoyancy regulation in dynamic lake environments. N. Z. J. Mar. Freshw. Res. 1987, 21, 379-390. [CrossRef]

29. Simioni, T.; Quadri, M.B.; Derner, R.B. Drying of Scenedesmus obliquus: Experimental and modeling study. Algal Res. 2019, 39, 101428. [CrossRef]

30. Lavoie, A.; Mouget, J.-L.; de la Noüe, J. Measurement of freshwater micro-algae cell density with Percoll density gradients. J. Microbiol. Methods 1986, 4, 251-259. [CrossRef]

31. Song, Y.; Zhang, L.-L.; Li, J.; Chen, M.; Zhang, Y.-W. Mechanism of the influence of hydrodynamics on Microcystis aeruginosa, a dominant bloom species in reservoirs. Sci. Total Environ. 2018, 636, 230-239. [CrossRef]

32. Wang, C.; Lan, C.Q. Effects of shear stress on microalgae-A review. Biotechnol. Adv. 2018, 36, 986-1002. [CrossRef]

33. Matthijs, H.C.P.; Visser, P.M.; Reeze, B.; Meeuse, J.; Slot, P.C.; Wijn, G.; Talens, R.; Huisman, J. Selective suppression of harmful cyanobacteria in an entire lake with hydrogen peroxide. Water Res. 2012, 46, 1460-1472. [CrossRef]

34. Fan, J.J.; Ho, L.; Hobson, P.; Brookes, J. Evaluating the effectiveness of copper sulfate, chlorine, potassium permanganate, hydrogen peroxide, and ozone on cyanobacterial cell integrity. Water Res. 2013, 47, 5153-5164. [CrossRef]

35. Xiao, M.; Li, M.; Reynolds, C.S. Colony formation in the cyanobacterium Microcystis. Biol. Rev. 2018, 93, 1399-1420. [CrossRef] [PubMed]

36. Daly, R.I.; Ho, L.; Brookes, J.D. Effect of chlorination on Microcystis aeruginosa cell integrity and subsequent microcystin release and degradation. Environ. Sci. Technol. 2007, 41, 4447-4453. [CrossRef] [PubMed] 
37. Zamyadi, A.; MacLeod, S.L.; Fan, Y.; McQuaid, N.; Dorner, S.; Sauvé, S.; Prévost, M. Toxic cyanobacterial breakthrough and accumulation in a drinking water treatment plant: A monitoring and treatment challenge. Water Res. 2012, 46, 1511-1523. [CrossRef] [PubMed]

38. Zamyadi, A.; Ho, L.; Newcombe, G.; Daly, R.I.; Burch, M.; Baker, P.; Prévost, M. Release and oxidation of cell-bound saxitoxins during chlorination of Anabaena circinalis cells. Environ. Sci. Technol. 2010, 44, 9055-9061. [CrossRef] [PubMed]

C 2019 by the authors. Licensee MDPI, Basel, Switzerland. This article is an open access article distributed under the terms and conditions of the Creative Commons Attribution (CC BY) license (http://creativecommons.org/licenses/by/4.0/). 